\title{
Dual RCA: culprit or companion
}

\author{
M Sudhakar Rao, Ashwal A Jayaram, Padmakumar Ramachandran, \\ Rohith Reddy Poondru
}

Department of Cardiology, Kasturba Medical College, Manipal University Manipal, Karnataka, India

\section{Correspondence to} Dr M Sudhakar Rao, msudhakar88@gmail.com

Accepted 6 July 2015

\section{(a) CrossMark}

\section{To cite: Rao MS,} Jayaram AA,

Ramachandran $\mathrm{P}$, et al. BMJ Case Rep Published online: [please include Day Month Year] doi:10.1136/bcr-2015210841

\section{DESCRIPTION}

A 55-year-old man presented with a 6-month history of New York Heart Association II exertional dyspnoea. There was no history of diabetes mellitus or hypertension. Being a reformed smoker, he was on treatment for obstructive airway disease. General and cardiovascular examinations were unremarkable. ECG showed loss of $\mathrm{R}$ wave progression in precordial leads. Echocardiography was normal. Coronary angiogram revealed selective opacification of two right coronary arteries arising from separate ostia of the same sinus coursing towards the right atrioventricular groove, which was confirmed by using separate views (figure 1 and video 1 ). The left coronary arteries were of normal origin and distribution.

Congenital coronary anomalies are seen in about $1 \%$ of the general population. ${ }^{1}$ Dual right coronary artery (RCA), either originating from single or separate ostia, is one of the rarest coronary artery anomalies and has only occasionally been mentioned in case reports. To date, dual RCA has been reported 40 times and detected in 46 patients in the literature. Dual RCA can have varied presentation. Being a benign entity, the first symptom is usually chest pain. However, the presentation may range from unstable angina to acute ST segment elevation myocardial infarction. ${ }^{2}{ }^{3}$ In the present case, the exertional dyspnoea may be attributable to underlying obstructive airway disease and dual RCA may be a benign companion.

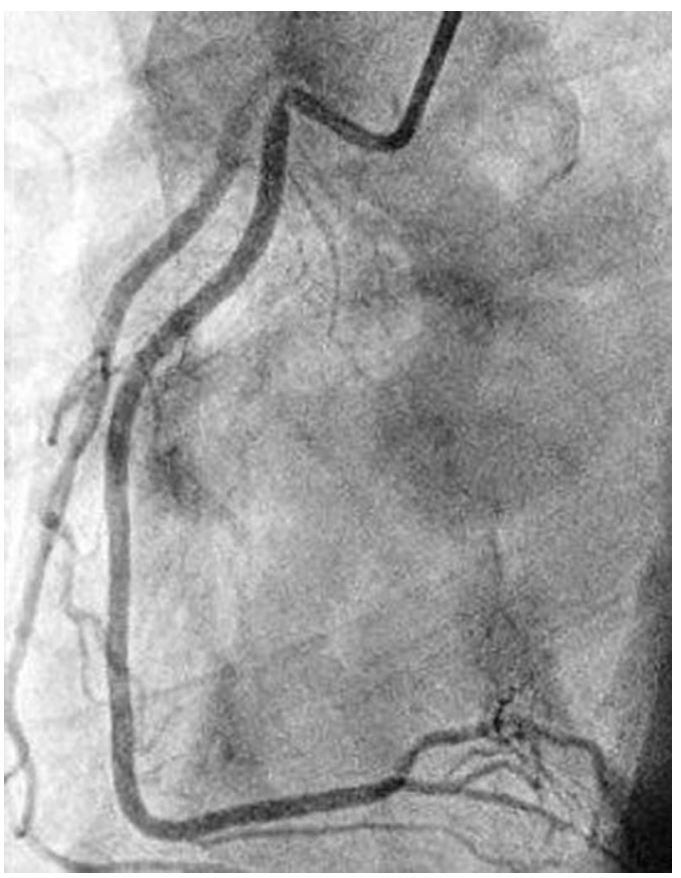

Figure 1 Left anterior oblique (LAO) cranial view showing dual right coronary artery arising from separate ostia of right coronary sinus.

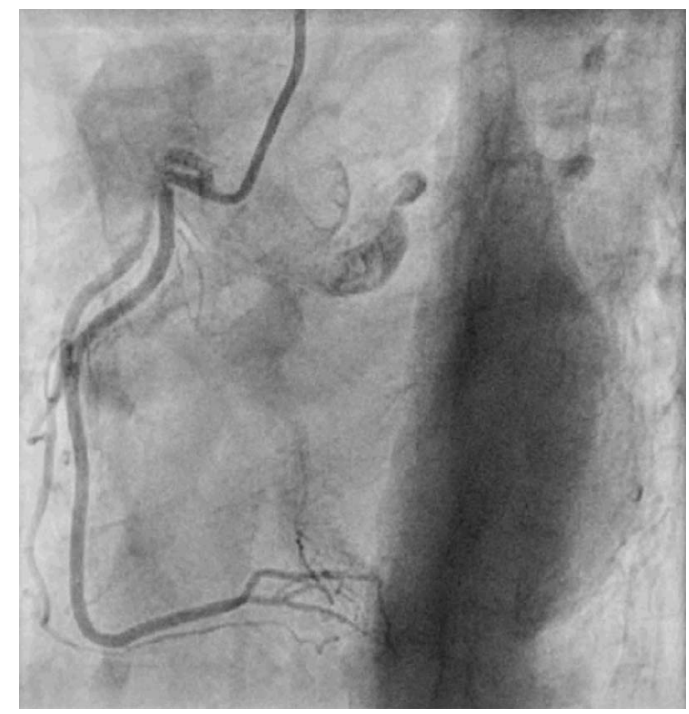

Video 1 Coronary angiogram in the left anterior oblique (LAO) plain view showing selective opacification of two right coronary arteries running parallel to each other towards the right atrioventricular groove and arising from separate ostia of the right coronary sinus.

\section{Learning points}

- Dual right coronary artery is a very rare entity, often benign, but it can sometimes be a precursor to acute coronary syndromes.

- Selective imaging of one of the coronaries can miss the disease in the other.

Twitter Follow M Sudhakar Rao at @suds

Acknowledgements The authors would like to acknowledge the patient and his relatives for their immense support during his hospitalisation.

Contributors RRP and MSR were involved in preparing the manuscript and all the above listed authors were involved in diagnosing, treating and follow-up of the case.

Competing interests None declared.

Provenance and peer review Not commissioned; externally peer reviewed.

\section{REFERENCES}

1 Jacobs ML, Mavroudis C. Anomalies of the coronary arteries: nomenclature and classification. Cardiol Young 2010;20(Suppl 3):15-19.

2 Tatli E, Buyuklu M, Altun A, et al. A patient with double right coronary artery and acute inferior myocardial infarction due to the critical lesion in one of them. Int J Cardiol 2007;119:e30-1.

3 Acet $\mathrm{H}$, Ozyurtlu F, Bilik MZ, et al. A rare coronary anomaly: atypical double right coronary artery with an acute inferior myocardial infarction. Korean Circ J 2012;42:208-11. 


\section{Images in...}

Copyright 2015 BMJ Publishing Group. All rights reserved. For permission to reuse any of this content visit http://group.bmj.com/group/rights-licensing/permissions.

BMJ Case Report Fellows may re-use this article for personal use and teaching without any further permission.

Become a Fellow of BMJ Case Reports today and you can:

- Submit as many cases as you like

- Enjoy fast sympathetic peer review and rapid publication of accepted articles

- Access all the published articles

- Re-use any of the published material for personal use and teaching without further permission

For information on Institutional Fellowships contact consortiasales@bmjgroup.com

Visit casereports.bmj.com for more articles like this and to become a Fellow 